\title{
Self-employment and psychometric measure of risk aversion: a replication and extension
}

\author{
Marko Korhonen \\ Rauli Svento \\ Mikko Vaaramo
}

Corresponding author:

Professor Marko Korhonen

Department of Economics

University of Oulu

P.O. Box 4600

FIN-90014 Oulu

Finland

email: marko.korhonen@oulu.fi

\author{
Professor Rauli Svento \\ Department of Economics \\ University of Oulu \\ P.O. Box 4600 \\ FIN-90014 Oulu \\ Finland
}

\author{
Mr. Mikko Vaaramo \\ Department of Economics \\ University of Oulu \\ P.O. Box 4600 \\ FIN-90014 Oulu \\ Finland
}

\section{Acknowledgements}

We thank the late professor Paula Rantakallio (launch of NFBC1966), the participants in the 46y study and the NFBC project center. Mikko Vaaramo thanks Yrjö Jahnsson Foundation and Oulu University Graduate School (UniOGS) for their generous support.

Funding

NFBC1966 received financial support from University of Oulu Grant no. 24000692, Oulu University Hospital Grant no. 24301140, ERDF European Regional Development Fund Grant no. 539/2010 A31592. 


\begin{abstract}
We examine whether the psychometric feature, called fear of uncertainty, predicts self-employment choice by individuals. Using the most recent Northern Finland birth cohort 1966 (NFBC1966) data from 2012, we find no clear evidence of such an effect. We also explore whether this effect might have changed due to increase of females in labor market, endogenous adaptation in risk preferences or because of the self-employment experience itself affects risk preferences. These effects are not significant, either.
\end{abstract}




\section{Introduction}

In a widely cited study Ekelund et al. (2005) uses unique psychometric data from Northern Finland birth cohort 1966 (NFBC1966) from 1997 to explore whether risk prone persons are more likely to choose self-employment instead of being employee. They show that the Cloninger (1987) temperament trait, called fear of uncertainty, as a proxy for risk aversion has a negative effect on selfemployment status, implying that the less risk averse person is more likely to be self-employed.

The NFBC1966 individuals were questioned again in 2012. This allows us to re-evaluate Ekelund et al. (2005) result by using the more recent questionnaire. We find mixed evidence across these surveys. The obvious evidence that the increase of the number of self-employed females due to the decrease in maternity figures in 2012 compared to 1997 figures among the 1966 cohort members could not explain this result.

Based on these findings, we explore the NFBC1966 data more deeply to find out the potential reasons related to personality causation. First, we examine whether there exist an endogenous adaptation in risk preferences. Caliendo et al. (2009) and Brachert et al. (2017) show that for entrepreneurs, risk attitudes may change considerably during their entrepreneurial career. Using the time dimension of our data we are able to explore reverse causality, which emerges if self-employment affects risk taking.

Second, we investigate whether there are differences in changes of risk preferences between the selfemployed and the employees. In our approach, one of the groups is exposed to self-employment treatment after first survey data 1997 but not before that. The second group is not exposed to the treatment in either period. In this way we can explore whether individuals self-employment experience (even a short one) has affected their psychometric risk aversion

We find only a slight but non-significant increase in the psychometric risk aversion measure of fear of uncertainty for those individuals who have been self-employed in both survey periods (1997 and 2012). Results also show that the treatment effects from employment to self-employment or selfemployment to employment do not change individuals' psychometrics risk preferences.

\section{Psychometric measure of risk aversion and the NFBC data}

Already Knight (1921) highlighted the importance of risk and uncertainty in self-employment. In economics, risk is defined as the case where individual has information about the probability of 
different outcomes and is able to choose between different alternatives. In contrast, uncertainty occurs when individual is ignorant for both true probability distribution and the outcomes of random draw.

Many of the measures of risk preferences are designed to reveal more economic risk taking than uncertainty. The research related to the psychometric measures of risk preferences is very limited, implying that it is not always clear whether a particular psychometric risk measure is expressing economic risk taking or some other risk domain (Beauchamp et al 2017). In Table 1 we present some recent studies of risk measures and self-employment.

\section{<INSERT TABLE 1 HERE>}

The NFBC1966 data included all babies born in provinces of Oulu and Lapland (approximately the northern half of Finland) with the expected due date in 1966. There was a total of 12231 babies, 6265 boys and 5964 girls. The NFBC1966 data has been gathered through clinical examinations, postal questionnaires, various hospital records and national register data.

For risk aversion measurement, we used psychometric data (the Cloninger (1987) biosocial concept of personality) for temperament subscale called fear of uncertainty (HA2), which is the second subscale of Harm Avoidance (HA). Cloninger described people with high fear of uncertainty as tense, fearful and apprehensive. Low fear of uncertainty represents calmness, confidence and incautiousness in situations that worry most people.

We only included full-time employees and self-employed individuals. After removing those individuals for which we have missing data points, we were left with 4025 individuals, of which 3639 are full-time employees and 386 self-employed.

\section{Empirical results}

In column 1 of Table 2, we show the replication results for Ekelund et al. (2005) study using the same model structure and covariates but with our data for the year $1997^{1}$. Since our background variables come from a couple of different questionnaires, we unfortunately missed some individuals that Ekelund et al. had included, but we also included some others that they had missed. We also have slightly different variables for the number of children and parents in self-employment. We find that

\footnotetext{
${ }^{1}$ Since we have NFBC1966 data only for individuals who participated study in 2012, we unfortunately miss some individuals that are in Ekelund et al (2005).
} 
the risk aversion coefficient is negatively associated at the 5\% level of significance to selfemployment choice. The parameter value is $-.071 .^{2}$

The column 2 presents the same regression model as column 1 but uses the 2012 survey data. Now, our evidence shows that the risk aversion parameter gets the value -.038, but it is non-significant. The control variables that are significant at 5\% level of significance predicting self-employment choice are gender, higher education degree, vocational degree and unemployment defined as the number of years of unemployment.

\section{<INSERT TABLE 2 HERE>}

Due to a significant decrease in maternity leave figures between 1997 and 2012, there are markedly more females in labor force data in 2012 survey. However, our results for gender-specific regressions in Table 2 (columns 3 and 4) show that the relation between psychometrics risk aversion measure and self-employment choice is robust against the gender differences.

For robustness, we examined whether the self-reported net wealth of household or the level of education can explain our findings. We divided our sample in subgroups (self-reported high vs. low net wealth and more vs. less educated), but our main result remains. To save the space we do not report these results here, but they are available upon a request.

We proceed with exploring potential reasons for the non-significant result of fear on uncertainty predicting self-employment choice in 2012 survey. We start by considering whether the selfemployment experience might have affected risk preferences. The related explanation is that the accumulated entrepreneurship-specific human capital and experience in a particular business might increase the confidence of self-employers and affect their risk attitudes (see Das and Teng 1997, Bowles 1998 and Janney and Dess 2006 among others).

We explored changes in mean values of risk aversion measurement within four different groups. For each group, we computed risk aversion averages for both survey years 1997 and $2012^{3}$. The first group is those individuals who were employees in both years 1997 and 2012. The second group is for those who changed from full-time job in 1997 to self-employment sometime between the years 1997 and 2012. The third group is for those who changed self-employment in 1997 to full-time job sometime between 1997 and 2012. Finally, the fourth group is for those who were self-employed in

\footnotetext{
${ }^{2}$ In the Ekelund et al. original study, the parameter value was -.086, and it was also significant at a $5 \%$ level of significance.

${ }^{3}$ This data are based on the timeline matrix developed by Ellen Ek to the 2012 survey. It is important to mention that we are able to use 1997 data only for those individuals who answered in both follow-up studies, 1997 and 2012.
} 
both years 1997 and 2012. As we can see from Table 3, there were only small changes in individual average risk aversion measurements within groups. All changes are statistically insignificant. The largest difference is for individuals who were self-employed for both survey periods 1997 and 2012, where the difference HA2(31y)-HA2(46y) is -.303 (p-value $=.219$ ).

\section{<INSERT TABLE 3 HERE>}

In Table 4, we give estimation results for the following regression

$$
H A 2_{i}=c+\alpha\left(\text { Treatment }_{i}\right)+\beta\left(\text { After }_{i}\right)+\gamma\left(\text { Treatment }_{i} * \text { After }_{i}\right)+u_{i},
$$

where, $c$ is constant, $H A 2_{i}$ is the fear of uncertainty for an individual $i$, Treatment $=1$ for selfemployed after 1997, 0 for others and After $=1$ for all individual's in 2012, 0 in 1997. Hence, the treatment effect, which in our case is the entry into self-employment, is affected only by one "group" (i.e., those who started self-employment after 1997 and stayed self-employed in 2012). The null hypothesis is $H_{0}: \gamma=0$. Evidence shows that there is no statistically significant ( $\mathrm{p}$-value $=.783$ ) change in fear of uncertainty across groups. Similarly, for those treatment group individuals who were self-employed in 1997 and 2012 and those who changed from self-employment to employment after 1997. The treatment effect is not statistically significant ( $\mathrm{p}$-value $=.218$ ) either. Our results suggest that the values of risk aversion measure (fear of uncertainty) have not significantly changed between 1997 and 2012 due to self-employment experience.

\section{<INSERT TABLE 4 HERE>}

It is not clear-cut whether the fear of uncertainty actually measures an individual's risk taking in economic and financial situations. The survey questions related to fear of uncertainty in NFBC1966 are measuring worrying in unfamiliar situations, fearing in physically dangerous situations and taking dangerous risks - instead of just being inactive, than taking economic risks.

In addition, Borghans et al. (2014) presents that harm avoidance, which is the second sub-group of the fear of uncertainty, has commonalities with Neuroticism (also called Emotional Stability) in the Big Five personality traits. Hogan and Hogan (2007) definition for Neuroticism is "the degree to which a person experiences the world as threatening and beyond his/her control". In their metaanalysis Zhao and Seibert (2006) show that entrepreneurs score lower on Neuroticism than managers. Since fear of uncertainty is shown to be positively related to neuroticism, one possible explanation four our result could be that the fear of uncertainty measures more unmeasurable risk or risk ambiguity that are perhaps more managerial features. 
The other possible explanation might be that emotion of fear of uncertainty in self-employment is related to fear of failure. In 2012 survey, cohort members are 15 years older and probably learned over time the possible returns of their activity. Unfortunately, fully understanding the role of fear of uncertainty is difficult due to component attributed to it.

\section{Conclusions}

Using the most recent data NFBC1966 from 2012, we find in contrast to Ekelund et al. (2005) that the temperament subscale "fear of uncertainty" does not predict the probability to be self-employed. Neither an increase of females in labor market because of less maternity leave individuals in the data set, nor the endogenous adaptation effect of risk preferences to decrease self-employers' risk aversion during the several years of experiment in self-employment can explain our result. For the further studies, it important to reveal what type of risk measure fear of uncertainty actually is.

\section{REFERENCES}

Beauchamp J.P., Cesarini D., Johannesson M. (2017). The psychometric and empirical properties of measures of risk preferences. Journal of risk and uncertainty, 54, 203-237.

Borghans, L., Duckworth, A.L., Heckman, J.J, \& ter Weel, B. (2008). The economics and psychology of personality traits. Journal of Human Resources, XLIII (4), 972-1059.

Bowles, S. (1998). Endogenous preferences: The cultural consequences of markets and other economic institutions. Journal of Economic Literature, 36(1), 75-111.

Brachert, M. , Hyll, W., \& Titze, M. (2017). On the simultaneity bias in the relationship between risk attitudes, entry into entrepreneurship and entrepreneurial survival. Applied Economics Letters, 24(7), 477-480.

Brown S., Dietrich M., Ortiz-Nuñez A., Taylor K. (2011). Self-employment and attitudes towards risk: Timing and unobserved heterogeneity. Journal of Economic Psychology, 32(3), 425-433.

Caliendo, M., Fossen, F., \& Kritikos, A. S. (2009). Risk attitudes of nascent entrepreneurs - new evidence from an experimentally-validated survey. Small Business Economics, 32(2), 153-167.

Caliendo M., Fossen F., Kritikos A. (2010). The impact of risk attitudes on entrepreneurial survival. Journal of Economic Behavior \& Organization, 76, 45-63 
Caliendo M., Fossen F., Kritikos A.S. (2014). Personality characteristics and the decisions to become and stay self-employed. Small Business Economics, 42, 787-814.

Cloninger, C. R. (1987). A systematic method for clinical description and classification of personality variants: A proposal. Archives of General Psychiatry, 44(6), 573-588.

Das, T. K., \& Teng, B. S. (1997). Time and entrepreneurial risk behavior. Entrepreneurship: Theory and Practice, 22(2), 69-71.

Ekelund, J, Johansson, E., Järvelin, M-L., \& Lichtermann, D. (2005). Self-employment and risk aversion - evidence from psychological test data. Labour Economics 12(5), 649-659.

Hogan, R., \& Hogan, J. (2007). Hogan Personality Inventory Manual, Third Edition. Tulsa, OK: Hogan Assessment Systems.

Holm H.J., Opper S., Nee V. (2013). Entrepreneurs Under Uncertainty: An Economic Experiment in China. Management Science, 59(7), 1671-1687

Janney, J. J., \& Dess, G. G. (2006). The risk concept for entrepreneurs reconsidered: New challenges to the conventional wisdom. Journal of Business Venturing, 21(3), 385-400.

Koudstaal M., Sloof R., van Praag M. (2016). Risk, Uncertainty, and Entrepreneurship: Evidence from a Lab-in-the-Field Experiment. Management Science, 62(10), 2897-2915.

Zhao, H. \& S.E. Seibert. (2006). The big five personality dimensions and entrepreneurial status: A meta-analytic review. Journal of Applied Psychology, 90, 1265-1272. 
Table 1. Recent studies related to risk measures and self-employment

\begin{tabular}{|c|c|c|c|c|c|c|}
\hline Study & Focus group & Control Group & Region & Method & $\begin{array}{l}\text { Risk } \\
\text { measurement }\end{array}$ & Result \\
\hline $\begin{array}{l}\text { Ekelund et al } \\
(2005)\end{array}$ & $\begin{array}{l}\text { Self-employed } \\
(\mathrm{n}=258)\end{array}$ & $\begin{array}{l}\text { Employees } \\
(n=2954)\end{array}$ & $\begin{array}{l}\text { Finland } \\
\text { Northern } \\
\text { Finland Birth } \\
\text { Cohort } 1966\end{array}$ & Survey & $\begin{array}{l}\text { Fear of } \\
\text { uncertainty }\end{array}$ & $\begin{array}{l}\text { Low fear of } \\
\text { uncertainty predicts } \\
\text { higher probability } \\
\text { to be self-employed }\end{array}$ \\
\hline $\begin{array}{l}\text { Caliendo et al. } \\
\text { (2010) }\end{array}$ & $\begin{array}{l}\text { Remaining in } \\
\text { self- } \\
\text { employment } \\
(n=4731)\end{array}$ & $\begin{array}{l}\text { Exiting from } \\
\text { self- } \\
\text { employment } \\
(\mathrm{n}=569)\end{array}$ & $\begin{array}{l}\text { Germany } \\
\text { German Socio- } \\
\text { Economic } \\
\text { Panel (SOEP) }\end{array}$ & Survey & Risk tolerance & $\begin{array}{l}\text { Medium risk } \\
\text { tolerance predicts } \\
\text { entrepreneurial } \\
\text { survival. }\end{array}$ \\
\hline $\begin{array}{l}\text { Brown et al. } \\
(2011)\end{array}$ & $\begin{array}{l}\text { Self-employed } \\
(\mathrm{n}=445)\end{array}$ & $\begin{array}{l}\text { Heads of } \\
\text { households } \\
\text { (not self- } \\
\text { employed) } \\
(n=4775)\end{array}$ & $\begin{array}{l}\text { United States } \\
\text { US Panel } \\
\text { Study of } \\
\text { Income } \\
\text { Dynamics }\end{array}$ & Survey & $\begin{array}{l}\text { Hypothetical } \\
\text { gambles with } \\
\text { respect to } \\
\text { lifetime income }\end{array}$ & $\begin{array}{l}\text { Low risk aversion } \\
\text { predicts self- } \\
\text { employment. }\end{array}$ \\
\hline $\begin{array}{l}\text { Holm et al. } \\
\text { (2013) }\end{array}$ & $\begin{array}{l}\text { Random sample } \\
\text { of CEO's } \\
\text { (entrepreneurs) } \\
(\mathrm{n}=700)\end{array}$ & $\begin{array}{l}\text { Randomly } \\
\text { sampled non- } \\
\text { entrepreneurs } \\
(n=200)\end{array}$ & China & Experiment & Multiple & $\begin{array}{l}\text { No difference in } \\
\text { self-employed in } \\
\text { risk or ambiguity } \\
\text { aversion. Self- } \\
\text { employed less } \\
\text { averse for strategic } \\
\text { uncertainty related } \\
\text { to competition and } \\
\text { trust. }\end{array}$ \\
\hline $\begin{array}{l}\text { Caliendo et al. } \\
\text { (2014) }\end{array}$ & $\begin{array}{l}\text { Self-employed } \\
(\mathrm{n}=5293 \text { person- } \\
\text { years })\end{array}$ & $\begin{array}{l}\text { Job market } \\
\text { participants } \\
\text { (not self- } \\
\text { employed) } \\
\text { (n=55408 } \\
\text { person-years) }\end{array}$ & $\begin{array}{l}\text { Germany } \\
\text { German Socio- } \\
\text { Economic } \\
\text { Panel (SOEP) }\end{array}$ & Survey & Risk tolerance & $\begin{array}{l}\text { Risk tolerance is } \\
\text { positively related to } \\
\text { probability to be } \\
\text { self-employed. }\end{array}$ \\
\hline $\begin{array}{l}\text { Koudstaal et } \\
\text { al. (2016) }\end{array}$ & $\begin{array}{l}\text { Entrepreneurs } \\
(\mathrm{n}=910)\end{array}$ & $\begin{array}{l}\text { Employees } \\
\text { and managers } \\
(\mathrm{n}=1378)\end{array}$ & Netherlands & Experiment & Multiple & $\begin{array}{l}\text { Entrepreneurs are } \\
\text { less risk averse and } \\
\text { loss averse than } \\
\text { control groups. No } \\
\text { difference in } \\
\text { ambiguity aversion. }\end{array}$ \\
\hline $\begin{array}{l}\text { Beauchamp et } \\
\text { al (2017) }\end{array}$ & $\begin{array}{l}\text { Participants who } \\
\text { have run their } \\
\text { own business } \\
(n=\sim 2500)\end{array}$ & $\begin{array}{l}\text { Other } \\
\text { participants } \\
(n=\sim 11000)\end{array}$ & $\begin{array}{l}\text { Sweden } \\
\text { SALTY Twin } \\
\text { Study }\end{array}$ & Survey & $\begin{array}{l}\text { Multiple risk } \\
\text { attitude } \\
\text { measurements. } \\
\text { Behavioral } \\
\text { Inhibition }\end{array}$ & $\begin{array}{l}\text { Self-employed are } \\
\text { less risk averse. } \\
\text { High risk averse } \\
\text { people are } \\
\text { behaviorally } \\
\text { inhibited. }\end{array}$ \\
\hline
\end{tabular}


Table 2. The logit estimation results for probability of self-employment.

\begin{tabular}{|c|c|c|c|c|}
\hline & 1997 Data & 2012 Data & Male & Female \\
\hline Intercept & $\begin{array}{l}-2.409^{* * *} \\
(0.217)\end{array}$ & $\begin{array}{l}-2.396^{\star \star \star} \\
(0.220)\end{array}$ & $\begin{array}{l}-2.015^{\star \star *} \\
(0.281)\end{array}$ & $\begin{array}{l}-2.297^{* \star *} \\
(0.317)\end{array}$ \\
\hline Male & $\begin{array}{l}0.524^{\star * *} \\
(0.140)\end{array}$ & $\begin{array}{l}0.460^{\star \star *} \\
(0.114)\end{array}$ & & \\
\hline HA2: Fear of uncertainty & $\begin{array}{l}-0.071^{\star \star} \\
(0.036)\end{array}$ & $\begin{array}{l}-0.038 \\
(0.033)\end{array}$ & $\begin{array}{l}-0.040 \\
(0.043)\end{array}$ & $\begin{array}{l}-0.033 \\
(0.052)\end{array}$ \\
\hline Fathdead + & $\begin{array}{l}-0.601^{*} \\
(0.344)\end{array}$ & $\begin{array}{l}-0.112 \\
(0.249)\end{array}$ & $\begin{array}{l}-0.262 \\
(0.364)\end{array}$ & $\begin{array}{l}0.007 \\
(0.342)\end{array}$ \\
\hline Parent self-emp. & $\begin{array}{l}0.711^{\star \star \star} \\
(0.130)\end{array}$ & $\begin{array}{l}0.159 \\
(0.120)\end{array}$ & $\begin{array}{l}0.419 * * * \\
(0.158)\end{array}$ & $\begin{array}{l}-0.201 \\
(0.193)\end{array}$ \\
\hline Married & $\begin{array}{l}-0.014 \\
(0.151)\end{array}$ & $\begin{array}{l}-0.053 \\
(0.122)\end{array}$ & $\begin{array}{l}-0.045 \\
(0.168)\end{array}$ & $\begin{array}{l}-0.046 \\
(0.179)\end{array}$ \\
\hline Child (under18) & $\begin{array}{l}0.094 \\
(0.058)\end{array}$ & $\begin{array}{l}0.069^{\star} \\
(0.039)\end{array}$ & $\begin{array}{l}0.106^{* *} \\
(0.046)\end{array}$ & $\begin{array}{l}-0.020 \\
(0.073)\end{array}$ \\
\hline House owner & $\begin{array}{l}0.380^{\star \star \star} \\
(0.139)\end{array}$ & $\begin{array}{l}0,041 \\
(0.170)\end{array}$ & $\begin{array}{l}0.044 \\
(0.239)\end{array}$ & $\begin{array}{l}0.065 \\
(0.242)\end{array}$ \\
\hline Higher educ. & $\begin{array}{l}-0.943^{* * *} \\
(0.256)\end{array}$ & $\begin{array}{l}-0.359^{* *} \\
(0.140)\end{array}$ & $\begin{array}{l}-0.491^{* *} \\
(0.206)\end{array}$ & $\begin{array}{l}-0.215 \\
(0.193)\end{array}$ \\
\hline Vocational educ. & $\begin{array}{l}0.511^{\star \star \star} \\
(0.136)\end{array}$ & $\begin{array}{l}0.256^{\star *} \\
(0.126)\end{array}$ & $\begin{array}{l}0.177 \\
(0.163)\end{array}$ & $\begin{array}{l}0.333 \\
(0.203)\end{array}$ \\
\hline Unempl. & $\begin{array}{l}-0.243^{\star \star *} \\
(0.069)\end{array}$ & $\begin{array}{l}-0.079^{\star *} \\
(0.039)\end{array}$ & $\begin{array}{l}-0.073 \\
(0.051)\end{array}$ & $\begin{array}{l}-0.092 \\
(0.059)\end{array}$ \\
\hline $\mathrm{N}$ & 2368 & 4025 & 1772 & 2253 \\
\hline
\end{tabular}

Notes: ${ }^{* *}$ Statistically significant at $1 \%$ significance level. ** Statistically significant at $5 \%$ significance level. *Statistically significant at $10 \%$ significance level. Standard errors are in parentheses.

+ Father passed away before participant was 14 -years old. 
Table 3. Fear of Uncertainty in 1997 HA2 (31 years) and 2012 HA2 (46 years)

\begin{tabular}{|c|c|c|c|c|c|c|c|}
\hline Occupation & & $N$ & Variable & Mean & $\begin{array}{l}\text { Standard } \\
\text { deviation }\end{array}$ & HA2(31y) - HA2(46y) & $\begin{array}{c}\text { t-test } \\
(p \text {-value })\end{array}$ \\
\hline \multirow[t]{2}{*}{$\begin{array}{l}\text { Employees in } \\
1997 \text { and } 2012\end{array}$} & 2012 & 1610 & HA2(46y) & 3.634 & 1.641 & -.024 & $\begin{array}{c}-.42 \\
(.690)\end{array}$ \\
\hline & 1997 & & HA2(31y) & 3.610 & 1.804 & & \\
\hline \multirow{2}{*}{$\begin{array}{l}\text { Self-employed in } \\
1997 \text { and } \\
\text { employees in } 2012\end{array}$} & 2012 & 91 & HA2(46y) & 3.308 & 1.379 & .121 & $\begin{array}{l}.50 \\
(.617)\end{array}$ \\
\hline & 1997 & & HA2(31y) & 3.428 & 1.844 & & \\
\hline \multirow{2}{*}{$\begin{array}{l}\text { Employees in } \\
1997 \text { and self- } \\
\text { employed in } 2012\end{array}$} & 2012 & 94 & HA2(46y) & 3.340 & 1.675 & -.096 & $\begin{array}{c}-.37 \\
(.714)\end{array}$ \\
\hline & 1997 & & HA2(31y) & 3.244 & 1.893 & & \\
\hline \multirow[t]{2}{*}{$\begin{array}{l}\text { Self-employed in } \\
1997 \text { and } 2012\end{array}$} & 2012 & 99 & HA2(46y) & 3.424 & 1.616 & -.303 & $\begin{array}{l}-1.23 \\
(.219)\end{array}$ \\
\hline & 1997 & & HA2(31y) & 3.121 & 1.836 & & \\
\hline
\end{tabular}


Table 4. Estimations between groups

Least squares means estimate

Employees in 1997 and 2012 vs employees in 1997 and self-employed in 2012

$\begin{array}{lllccr}\text { Treatment effect } & \text { Estimate } & \text { SE } & \text { z-value } & \text { p-value } & N \\ \gamma & 0.07152 & 0.1610 & 0.2592 & 0.7826 & 1704\end{array}$

Self-employed in 1997 and 2017 vs self-employed 1997 and employees 2012)

\begin{tabular}{llllll} 
Treatment effect & Estimate & SE & z-value & p-value & $N$ \\
$\gamma$ & -0.4239 & 0.3437 & 1.52 & 0.2175 & 190 \\
\hline
\end{tabular}




\section{APPENDIX}

Table A1. The logit estimation results for probability of self-employment in sub-groups.

\begin{tabular}{|c|c|c|c|c|}
\hline & High wealth & Low Wealth & Higher education & No Higher Educ. \\
\hline Intercept & $\begin{array}{l}-2.215^{\star * *} \\
(0.268)\end{array}$ & $\begin{array}{l}-2.588^{\star * \star} \\
(0.322)\end{array}$ & $\begin{array}{l}-2.355^{\star * *} \\
(0.473)\end{array}$ & $\begin{array}{l}-2.444^{\star \star *} \\
(0.242)\end{array}$ \\
\hline Male & $\begin{array}{l}0.628^{\star \star *} \\
(0.162)\end{array}$ & $\begin{array}{l}0.066 \\
(0.208)\end{array}$ & $\begin{array}{l}0.311 \\
(0.229)\end{array}$ & $\begin{array}{l}0.567^{* * *} \\
(0.129)\end{array}$ \\
\hline HA2: Fear of uncertainty & $\begin{array}{l}-0.035 \\
(0.045)\end{array}$ & $\begin{array}{l}0.020 \\
(0.059)\end{array}$ & $\begin{array}{l}-0.055 \\
(0.074)\end{array}$ & $\begin{array}{l}-0.032 \\
(0.037)\end{array}$ \\
\hline Fathdead + & $\begin{array}{l}-0.415 \\
(0.382)\end{array}$ & $\begin{array}{l}-0.206 \\
(0.413)\end{array}$ & $\begin{array}{l}0.006 \\
(0.534)\end{array}$ & $\begin{array}{l}-0.145 \\
(0.281)\end{array}$ \\
\hline Parent self-emp. & $\begin{array}{l}0.264 \\
(0.161)\end{array}$ & $\begin{array}{l}0.035 \\
(0.223)\end{array}$ & $\begin{array}{l}-0.144 \\
(0.288)\end{array}$ & $\begin{array}{l}0.227^{\star} \\
(0.134)\end{array}$ \\
\hline Married & $\begin{array}{l}-0.301^{*} \\
(0.169)\end{array}$ & $\begin{array}{l}0.032 \\
(0.206)\end{array}$ & $\begin{array}{l}-0.316 \\
(0.253)\end{array}$ & $\begin{array}{l}0.038 \\
(0.140)\end{array}$ \\
\hline Child (under18) & $\begin{array}{l}0.105^{\star *} \\
(0.050)\end{array}$ & $\begin{array}{l}-0.006 \\
(0.081)\end{array}$ & $\begin{array}{l}0.006 \\
(0.094)\end{array}$ & $\begin{array}{l}0.078^{\star} \\
(0.043)\end{array}$ \\
\hline Houseowner & - & - & $\begin{array}{l}0.071 \\
(0.379)\end{array}$ & $\begin{array}{l}0.030 \\
(0.190)\end{array}$ \\
\hline Higher educ. & $\begin{array}{l}-0.389^{\star \star} \\
(0.180)\end{array}$ & $\begin{array}{l}-0.320 \\
(0.273)\end{array}$ & & \\
\hline Vocational educ. & $\begin{array}{l}0.504^{\star * *} \\
(0.178)\end{array}$ & $\begin{array}{l}0.274 \\
(0.225)\end{array}$ & & \\
\hline Unempl. & $\begin{array}{l}-0.022 \\
(0.060)\end{array}$ & $\begin{array}{l}-0.067 \\
(0.059)\end{array}$ & $\begin{array}{l}-0.012 \\
(0.108)\end{array}$ & $\begin{array}{l}-0.085^{\star *} \\
(0.042)\end{array}$ \\
\hline $\mathrm{N}$ & 1821 & 1481 & 1253 & 2474 \\
\hline
\end{tabular}

Notes: ${ }^{* *}$ Statistically significant at $1 \%$ significance level. ${ }^{* *}$ Statistically significant at $5 \%$ significance level.

*Statistically significant at $10 \%$ significance level. Standard errors are in parentheses.

+ Father passed away before participant was 14 -years old. 